\title{
Preliminary References under Eu Law
}

\author{
Armin Cuyvers
}

\subsection{Introduction}

The preliminary reference procedure allows national courts to ask questions on EU law to the Court of Justice of the European Union (CJEU). The importance of preliminary references becomes readily apparent when one realizes the EU has over 500 million citizens and companies, but there are only 84 judges in the EU Court in Luxembourg. Consequently, it is the tens of thousands of national judges that have to uphold and apply EU law in practice. It is these national judges that have to turn EU law into a living, enforceable reality within each Member State. ${ }^{1}$

Because of their central role, it is essential that all these national courts apply EU law correctly and consistently. The application of EU law, after all, should not depend on which national judge you happen to end up with. At the same time, a uniform application of EU law is far from automatic. Each lawyer is shaped by his or her own national legal system and culture, and will unavoidably approach EU law from this national perspective, even if it is often unwittingly so. Without guidance, therefore, it is likely that a British lawyer with a common law background and a French lawyer with a civil law background would arrive at different interpretations of the same EU law concepts, even though these concepts have their autonomous EU meaning and should not be affected by national law. To protect the unity and effectiveness of EU law, therefore, it is essential that the Court of Justice provides guidance on the correct interpretation of EU law, and is enabled to assist national courts that are faced with certain doubts about the right interpretation of EU law. ${ }^{2}$

The preliminary reference mechanism is one of the key instruments enabling the CJEU to provide this guidance, and cooperate with national

1 For more elaborate discussion of the preliminary reference procedure see inter alia M. Broberg and N. Fenger, Preliminary References to the European Court of Justice (oup, 2nd edn, 2014), and on the process in new Member States, which maybe of special interest to the EAC, M. Bobek, 'Learning to talk: Preliminary Rulings, the Courts of the New Member States and the Court of Justice' (2008) 45 CMLRev 1611.

2 Cf. Opinion 1/og Patent Court [2011] ECR I-1137. 
courts. Indeed, many of the most foundational rulings on EU law, including Van Gend \& Loos and Costa v. E.N.E.L. were given in preliminary reference proceedings, further illustrating the importance of this mechanism. ${ }^{3}$ This chapter systematically discusses the different legal issues and complications preliminary references may give rise to, and the legal solutions developed in the $\mathrm{EU}$ to ensure the proper functioning of this mechanism. To structure this discussion, it follows the different steps of a preliminary ruling procedure, starting with the question of which bodies are allowed to ask references, and if national law is allowed to limit the right of courts to ask a reference. Subsequently, this chapter discusses when national courts may actually have an obligation to ask a preliminary reference, instead of just a right, or conversely, when the CJEU may declare a preliminary reference inadmissible. Lastly, it must be discussed what the CJEU may rule on in a preliminary judgment, and what a national court should do with the preliminary judgment it receives from the CJEU.

\subsection{Courts and Tribunals Allowed to Refer a Preliminary Question}

Article 267 TFEU states that a preliminary question may be asked by 'any court or tribunal of a Member State. The CJEU by now has clarified that to qualify as a court or tribunal, a body must meet all, or at least most, of the following criteria to a high degree:
i. It has to be established by law;
ii. It has to be permanent;
iii. It must have compulsory jurisdiction;
iv. It must deal with procedures inter partes;
v. It must apply rules of law
vi. And lastly it must be independent. ${ }^{4}$

Whether a specific body qualifies has to be assessed on a case-by-case basis, whereby the CJEU tends to be supportive of the body wanting to refer where possible. ${ }^{5}$ The CJEU has, however, adhered to its position that normally arbitral tribunals do not qualify as a court or tribunal under Article 267 TFEU, unless

3 See also F. Mancini and D. Keeling, 'From CILFIT to ERT: The Constitutional Challenge Facing the European Court' (1991) 11 YBEL, 1.

4 See Case C-14/86 Pretore di Salò ECLI:EU:C:1987:275, or more recently Case C-210/o6 Cartesio ECLI:EU:C:2008:723.

5 See for example Case C-408/98 Abrahamsson ECLI:EU:C:200o:367. 
there is a very close link between the arbitration and the ordinary judicial system of a Member State. ${ }^{6}$ This might be understandable as many arbitral proceedings fail to meet many of the criteria given and many arbiters might not even want to ask a reference, taking into account the year and a half it takes on average to get an answer. Yet the inability of arbiters to refer questions to the CJEU is also increasingly problematic. To begin with, arbitration is becoming increasingly common. In addition, the cJEU has also held that arbiters are obligated to respect EU law of public order, such as EU competition law, in their awards. A failure to respect $\mathrm{EU}$ law therefore leads to an obligation on national judges to annul an arbitral award and to refuse execution. ${ }^{7}$ Arbiters, therefore, are bound by EU law, but are unable to ask guidance on it.

In the EAC context, the EACJ has already directly referred to Pretore di Salò in determining which Courts and Tribunals are allowed to refer a question to it. ${ }^{8}$ Building on this solid start, one may also consider if these criteria could perhaps be further developed to take the specific context of East Africa into account, for example by including systems of customary law or dispute settlement into the circle of courts and tribunals that are allowed to refer. In addition, the EAC may have an opportunity to reconsider the standing of arbitral awards, and perhaps find a more balanced solution than the one chose in the EU.

\subsection{The Sacred Right to Refer}

The CJEU has made it very clear that the right of a court or tribunal to refer a question to the CJEU may never be limited. ${ }^{9}$ Neither national law nor higher courts are allowed to limit the freedom of a court to refer. For example, national higher courts may not prohibit lower courts to ask a preliminary question in a specific case or on a point they have already ruled upon in an injunction. Similarly, the cJEU held that a French draft-law that would obligate lower courts to first refer a question to the French Constitutional Court before

6 See for example Case C-102/81 Nordsee ECLI:EU:C:1982:107 or Case C-377/13 Ascendi Beiras ECLI:EU:C:2014:1754.

7 Case C-126/97 Eco Swiss v. Benneton ECLI:Eu:C:1999:269.

8 See Chapter 8 par.1 and Case Stated No. 1 of 2014 Attorney General of Uganda vs.and Tom Kyahurwenda [2015]. (EACJ, 2015) [54].

9 See already Case 166/73 Rheinmühlen-Düsseldorf ECLI:Eu:C:1974:3. 
they could refer a preliminary question to the CJEU violated the right of lower courts under Article 267 TFEU. ${ }^{10}$

No limit may be imposed, therefore, on the right of any court to ask a preliminary reference to the CJEU. By defending this absolute right of national courts, the CJEU also ensures that the channel of communication with lower courts remains open. Any risk that national law or higher courts may try to prevent any questions from reaching the CJEU is thereby addressed. In addition, this allows lower courts to enlist the support of the CJEU when they for example think a ruling of their own supreme court or an act of parliament conflicts with EU law. Lower courts may, justly so, have some reservations before overruling their own supreme courts through the supremacy of EU law, and may hence prefer some confirmation and borrowed authority from the CJEU. ${ }^{11}$ At the same time, lower courts must also carefully consider if, in a concrete case, it might perhaps not be better to leave it to the Court of Appeal to refer a question, as at that stage of the proceedings the facts of the case and the relevant legal issues may have been clarified and come into sharper focus.

\subsection{A Right or an Obligation to Refer?}

Article 267 TFEU makes a distinction between lower courts, which may refer a preliminary question and 'a court or tribunal of a Member State against whose decisions there is no judicial remedy', which shall refer a question to the CJEU when a question of EU law arises. In some cases, therefore, national courts actually have a legal obligation under EU law to ask a preliminary question. ${ }^{12}$

When deciding if an obligation to refer exists, it is useful to first distinguish between questions on the validity of $\mathrm{EU}$ law and questions on the interpretation of EU law. Subsequently, it is necessary to establish which courts fall under the obligation to refer, and which exceptions the CJEU has developed through its case law on the obligation to refer.

10 Case C-188/10 Melki en Abdeli ECLI:EU:C:2010:363.

11 See EU chapter 4 on the doctrine of supremacy. One of the effects of this supremacy is that lower courts can escape the normal judicial hierarchy, as their power to overturn or ignore a ruling from their own supreme court, or even a provision of their own constitution, derives from Eu law itself, not just from their own judicial authority.

12 The failure to do so may even lead to Member State liability for the breach of this obligation to refer, even if this action will only be successful in extreme cases. See Case C-224/o1 Köbler [2003] ECR I-10239. 


\subsubsection{Questions on Validity versus Questions on the Interpretation of EU Law}

National courts can refer two different kinds of question to the CJEU. The first type of question concerns the validity of EU law. Such a question essentially asks if a certain rule of $\mathrm{E} U$ law might be invalid because it conflicts with a higher norm of EU law. In Digital Rights Ireland, for example, the High Court of Ireland and the Austrian Verfassungsgerichtshof both asked a preliminary question on the validity of the data retention directive, as they thought this directive inter alia violated fundamental rights protected under the EU Charter. ${ }^{13}$ The second type of questions concerns the interpretation of EU law, and basically asks how a certain rule of EU law should be interpreted.

Since the CJEU is the only court with the authority to declare EU law invalid, national courts are always under an obligation to refer a validity question to the CJEU if they want to question the validity of an EU act. National courts are, therefore, allowed to hold that an EU act is valid, but not that an EU act is invalid. ${ }^{14}$ Consequently, the entire question of whether a court may or must refer a preliminary question only concerns the second type of questions, being questions on the interpretation of EU law.

\subsubsection{Courts with an Obligation to Refer}

Only courts against whose decision there is no remedy can be under the obligation to refer. This is a factual test that requires a case-by-case assessment. For example, national law may not allow an appeal from a court of first instance to a court of appeal if the monetary interest at stake is too low, or if the case concerns a labor dispute. In such cases, no remedy exists against the court of first instance, and even a court of first instance might be obligated to ask a preliminary reference. It is incorrect, therefore, to summarize Article 267 TF E U as holding that only supreme courts or constitutional courts are under an obligation to refer. The fact that a remedy depends on a supreme court accepting a case, or that an appeal to the supreme court is only allowed on points of law, however, does not make the decision of a court of appeal into a decision

13 Joined Cases C-293 and 594/12 Data Retention Directive, ECLI:Eu:C:2014:238.

14 The only, very limited, exception is that national courts may, in exceptional circumstances where irreparable harm may be caused by enforcing a rule of EU law, provide an interim measure disapplying that rule of EU law in the particular case whilst they await the preliminary ruling of the CJEU on validity. See Case 314/85 Foto-Frost [1987] ECR 4199. 
against which there is no remedy, even if the supreme court in the end refuses to hear the case. ${ }^{15}$

\subsubsection{Exceptions to the Obligation to Refer: The CILFIT Doctrine}

Even where no legal remedy exists, however, national courts may not be obligated to refer a question. In the famous CILFIT judgment the CJEU formulated three exceptions to the obligations to refer. Firstly, no obligation exists where the question of $\mathrm{EU}$ law 'is not relevant, that is to say, if the answer to that question, regardless of what it may be, can in no way affect the outcome of the case. ${ }^{16}$ Secondly, a reference is not required 'where previous decisions of the Court have already dealt with the point of law in question, irrespective of the nature of the proceedings which led to those decisions, even though the questions at issue are not strictly identical. ${ }^{\prime 17}$ This second exception is known as the acte eclairé doctrine, and means that courts do not have to ask questions of law that, in their opinion, have already been clarified in previous judgments of the CJEU. Of course whether the question at stake has really been settled by previous CJEU case law is an assessment the national courts has to make.

The third exception is known as the acte clair doctrine, and removes the obligation to refer where the correct interpretation of $\mathrm{EU}$ law is so obvious for the national court that no reference is deemed necessary. In the words of the CJEU: 'Finally, the correct application of Community law may be so obvious as to leave no scope for any reasonable doubt as to the manner in which the question raised is to be resolved. ${ }^{18}$ This third exception is potentially the most far reaching, as it creates the risk of national courts imposing their own, incorrect interpretation on EU law, either intentionally or unwittingly. For this reason the CJEU adds several warnings to national courts, and implores them to not assume that the correct interpretation is clear too easily:

Before it comes to the conclusion that such is the case, the national court or tribunal must be convinced that the matter is equally obvious to the courts of the other Member States and to the Court of Justice. Only if those conditions are satisfied, may the national court or tribunal refrain from submitting the question to the Court of Justice and take upon itself the responsibility for resolving it.

15 Case C-99/oo Kenny Roland Lykkeskog, ECLI:Eu:C:2002:329 and Case C-210/o6 Cartesio [2008] ECR I-9641.

16 Case 283/81 CILFIT ECLI:EU:C:1982:335, par. 10.

17 Idem, par. 14.

18 Idem, par. 16. 
However, the existence of such a possibility must be assessed on the basis of the characteristic features of Community law and the particular difficulties to which its interpretation gives rise.

To begin with, it must be borne in mind that Community legislation is drafted in several languages and that the different language versions are all equally authentic. An interpretation of a provision of Community law thus involves a comparison of the different language versions.

It must also be borne in mind, even where the different language versions are entirely in accord with one another, that Community law uses terminology which is peculiar to it. Furthermore, it must be emphasized that legal concepts do not necessarily have the same meaning in Community law and in the law of the various Member States.

Finally, every provision of Community law must be placed in its context and interpreted in the light of the provisions of Community law as a whole, regard being had to the objectives thereof and to its state of evolution at the date on which the provision in question is to be applied. ${ }^{19}$

At the same time, this does not mean that national high courts must refer every time some doubt remains. After all, it is part of the responsibility of high courts to settle doubts, even if there may be disagreements on the law with or between lower courts. As the CJEU recently clarified in Ferreira da Silva:

In itself, the fact that other national courts or tribunals have given contradictory decisions is not a conclusive factor capable of triggering the obligation set out in the third paragraph of Article $267 \mathrm{TFEU}$.

A court or tribunal adjudicating at last instance may take the view that, although the lower courts have interpreted a provision of EU law in a particular way, the interpretation that it proposes to give of that provision, which is different from the interpretation espoused by the lower courts, is so obvious that there is no reasonable doubt.

However, so far as the area under consideration in the present case is concerned and as is clear from paragraphs 24 to 27 of this judgment, the question as to how the concept of a 'transfer of a business' should be interpreted has given rise to a great deal of uncertainty on the part of many national courts and tribunals which, as a consequence, have found it necessary to make a reference to the Court of Justice. That uncertainty

19 Idem, paras 17-20. See for further discussion also D. Edward, 'CILFIT and Foto-Frost in their Historical and Procedural Context', in: The Past and Future of EU Law: The Classics of EU law Revisited on the 5oth Anniversary of the Rome Treaty (Hart Publishing 2010), 173. 
shows not only that there are difficulties of interpretation, but also that there is a risk of divergences in judicial decisions within the European Union.

It follows that, in circumstances such as those of the case before the referring court, which are characterised both by conflicting lines of caselaw at national level regarding the concept of a 'transfer of a business' within the meaning of Directive 2001/23 and by the fact that that concept frequently gives rise to difficulties of interpretation in the various Member States, a national court or tribunal against whose decisions there is no judicial remedy under national law must comply with its obligation to make a reference to the Court, in order to avert the risk of an incorrect interpretation of EU law. ${ }^{20}$

Although the CJEU therefore allows the acte clair doctrine to be applied where national lower courts disagree, it does not allow it where there is disagreement or confusion between the courts of multiple Member States. Such disagreement between Member States would threaten the uniformity of EU law and indicate the necessity of a preliminary ruling to provide an authoritative EU interpretation.

These exceptions to the obligation to refer, and the leeway granted to national courts by the $\mathrm{CJEU}$, reflect the cooperative nature of the preliminary reference procedure. The CJEU heavily relies on the national courts to refer the important cases to it, and to correctly implement the preliminary rulings it gives. Even though EU law itself is supreme, and national courts are under a legal obligation to implement any preliminary ruling given, the entire preliminary question mechanism depends on mutual respect and a good working relation between the CJEU and national courts. This mutual respect includes trusting national courts, certainly national supreme courts, to assess when a preliminary reference is required and when it is not. Vice versa, national courts must take seriously their duty to refer questions on interpretation, also as referring the right questions allows the CJEU to ensure the correct and uniform interpretation of $\mathrm{EU}$ law. 


\subsection{Admissibility of Preliminary References}

When a national court refers a question, the CJEU is in principle obligated to provide a preliminary answer. ${ }^{21}$ Ultimately, however, the CJEU retains the final say over its own jurisdiction, which means that it can also declare preliminary references inadmissible. Generally, the CJEU does not want to reject references, both out of respect for the national courts asking them and because it needs preliminary questions to fulfill its function. The CJEU will even try to 'rescue' poorly drafted questions where possible, so as to provide a helpful response to the national court. Over time, however, the cJEU has developed three general grounds on which a reference may be declared inadmissible.

Firstly, a reference is inadmissible where the question asked is obviously irrelevant to solve the dispute before the national court. ${ }^{22}$ Secondly, a reference may be declared inadmissible where the dispute between the parties is hypothetical. This concerns disputes that have been construed by the parties with the sole purpose of acquiring a judicial ruling on a certain question, but where there is no real dispute between the parties. ${ }^{23}$ Test-cases, however, are allowed, as long as there is a real dispute concerned. Lastly, the CJEU may also declare a reference inadmissible where the case file sent by the national court does not provide sufficient factual and legal information to usefully answer the questions posed. ${ }^{24}$ Of course a national court is then allowed to improve the file and resend it. ${ }^{25}$

The fact that a question asked by a national court has already been clarified in earlier case law, or the correct interpretation is obvious, is not a ground for inadmissibility. These CILFIT exceptions only remove the obligation of national courts to refer, they do not remove the right to refer where national courts want to do so.

\footnotetext{
21 See for example case C-220/05 Auroux ECLI:EU:C:2007:31.

22 Cf. Case C-293/03 My ECLI:Eu:C:2004:821 or Case C-152/03 Ritter-Coulais ECli:Eu: C:2006:123.

23 Case 244/80 Foglia ECLI:Eu:C:1981:302 or Case C-225/o2 Garcia Blanco ECLI:Eu:C:2005:34.

24 See for example Case C-567/o7 Sint-Servatius ECLI:EU:C:2009:593.

25 The CJEU has also provided national courts with a communication providing recommendations on how to submit preliminary references, published in of [2012] C 338/1.
} 


\subsection{Status and Effect of the Preliminary Ruling}

In a preliminary ruling, the CJEU may only rule on the validity of EU law or provide the correct interpretation of a rule of EU law. The CJEU is not allowed to interpret national law, or to settle the underlying dispute between parties. It remains up to the national court to apply the interpretation given by the CJEU to the case at hand. What the CJEU can do, however, is to provide an interpretation of EU law that is so specific, and is so closely linked to the facts of the case, that it de facto determines the decision the national court should take. ${ }^{26}$ In other cases, the CJEU may only provide a more general interpretation of EU law, and thereby leave a broad discretion to the national court, for example to determine the proportionality of a measure. ${ }^{27}$

A preliminary answer is legally binding on the national court that referred the question to the CJEU. ${ }^{28}$ In addition, a preliminary ruling is also binding on all other national courts, as it provides the authoritative interpretation of $\mathrm{EU}$ law. ${ }^{29}$ Preliminary rulings, therefore, have an erga omnes binding effect, and function as legal precedents. Normally, the interpretation provided by the CJEU also has retroactive effect, meaning it determines how the provision should always have been interpreted, also in the past (ex tunc). ${ }^{30}$ In exceptional cases, however, the CJEU may limit the effect of a preliminary reference in time, for example because legal certainty requires so or the practical implications of $e x$ tunc application would be to severe. In Defrenne, for example, the cJEu limited the effects of its ruling on equal pay between men and women based on (now) Article 157(1) TFEU, as full retroactive effect would require governments and companies to compensate lower wages going back for more than a decade. ${ }^{31}$

26 See for example Case C-180/04 Vasallo ECLI:Eu:C:2006:518.

27 See for an overview and analysis of different approaches T. Tridimas, 'Constitutional Review of Member State Action: The Virtues and Vices of an Incomplete Jurisdiction', (2011) 9 I-CON 737 .

28 Case 52/76 Benedetti ECLI:Eu:C:1977:16.

29 This obligation also derives from Article 4(3) TEU. See also Joined Cases 28-30/62 Da Costa ECLI:Eu:C:1963:6.

30 J. Komarek, 'Federal Elements in the Community Judicial System: Building Coherence in the Community Legal System', (2005) 42 CMLRev, 9 .

31 43/75 Defrenne $v$ SABENA (Defrenne II), ECLI:Eu:C:1976:56. Also see Case C-262/88 Barber ECLI:EU:C:1990:209. 